\title{
KRT16 Gene
}

National Cancer Institute

\section{Source}

National Cancer Institute. KRT16 Gene. NCI Thesaurus. Code C118928.

This gene plays a role in the formation of both skin and hair. 